\title{
THE NATURE OF ULTRA-ORTHODOX RESPONSES TO THE HOLOCAUST
}

\author{
Dan Garner*
}

\begin{abstract}
This study examines the religious response to the Shoah of Rabbi Kalonymous Shapira, a Chasidic leader in the Warsaw Ghetto during the Second World War. The responses of the UltraOrthodox to the Holocaust have long been neglected and/or marginalized, only coming back into considered focus in more recent years. These responses were often associated with the idea of 'punishment for sin' in relation to theological justification of the Holocaust. Yet Shapira's response contains surprising elements concerning his attempt to understand theologically the unfolding sufferings through which he and his community lived (and died). These surprising tendencies can be characterized as 'atheodic' and 'antitheodic' in nature in that they evidence the relinquishing of the effort to justify and explain the suffering. Together these tendencies show Shapira's response to be both more complex and sensitive than Ultra-Orthodox thought has often been given credit for.
\end{abstract}

\section{Introduction}

Within the scholarly literature there has been much discussion of the variety of theological responses to the Holocaust. However, for reasons that will be examined below, little interest has been shown in responses emanating from within Ultra-Orthodox circles. It is only in more recent years that the complexity and depth present within these charedi responses has really started to be taken seriously. ${ }^{1}$ At the same time as these responses have become more widely known, the scholarship of Holocaust theology in general has been significantly advanced by the work of Zachary Braiterman, who has provided an original and useful analysis of the field by developing the idea of 'antitheodicy'. In this paper I will seek to develop further Braiterman's analysis through a constructive criticism of his concept, and then attempt to apply this new analysis to the Ultra-Orthodox response of Rabbi Kalonymos Shapira, in order to uncover the complexity and depth present in this particular UltraOrthodox response. Key to this undertaking will be the recognition of a religious response to suffering and evil that I will term 'atheodicy'. The argument will be developed over three main parts. Part one will examine the consensus view of the Ultra-Orthodox responses to the Holocaust, part two will examine and critique Zachary Braiterman's concept of antitheodicy, and part three will explore Shapira's response to the Holocaust, demonstrating the antitheodic and atheodic content within it; consequently revealing the deep complexity of Shapira's Holocaust theology. In light of this it will be shown that the charedi responses

\footnotetext{
* PhD candidate, University of Manchester. Email: thebluetemple@yahoo.co.uk

${ }^{1}$ For a comprehensive overview of Ultra-Orthodox responses to the Holocaust see part one of S. Katz, S. Bider and G. Greenberg, eds., Wrestling With God: Jewish Responses During and After The Holocaust (New York: Oxford University Press, 2006).
} 
have not solely relied upon a one-dimensional theodicy to deal with the religious problems raised by the Holocaust.

\section{Common Views of the Ultra-Orthodox Response}

It is only since the 1990s that scholars working within Holocaust theology have begun seriously to focus on the variety of Ultra-Orthodox thought related to the Holocaust. There are a number of possible reasons for this, but one of the primary reasons is that many of the sources were until that time unavailable in English translation, being found only in Hebrew or Yiddish. As well as this, these responses have also been marginalised by being characterized as relying on one-dimensional extremist theodical positions. The Ultra-Orthodox have often been associated with promoting the idea that the Shoah was a punishment sent by God in response to the Jewish sins of assimilation and/or Zionism. This broad characterization of the Ultra-Orthodox views can be clearly seen when Zachary Braiterman states, "In our own day, ultra-Orthodox Jews explain and accept the Holocaust as God's response to the putative sins of assimilation and Zionism." Steven Katz has also stated that, "Satmar Hasidim and other right-wing Orthodox Jews . . continue to account for the Holocaust through recourse to the doctrine of 'for our sins we are punished'".

[2]There is in fact good reason for such a charge to be laid at the door of some of the charedi rabbis who have attempted to deal theologically with the Holocaust. Most prominent and controversial of these is Rabbi Yoel Teitelbaum (1887-1979) of the Satmar Chasidic community. Despite being a survivor of the Shoah he still developed a theological response to the suffering based primarily on the idea of punishment for sin. He stated, "It is because of the Zionists that six million Jews were killed. The fact is that this is the bitter punishment stipulated in the Talmud ... (Tractate Ketuboth 111) which results in the payment of a spiritual and physical debt from the Jewish People. Afflictions and tribulations only appear in this world because of the wicked, and the punishment is meted out first upon the righteous." One leading scholar of charedi responses, Gershon Greenberg, further explains Teitelbaum's position: "the people of Israel were sworn not to rebel against the nations that ruled them in exile, and they were not to hasten the end of history . . . by ascending to the land of Israel en masse. The nations, conditional on these two oaths, were sworn not to overly oppress the people of Israel. ${ }^{\prime 5}$

However, to take Teitelbaum's view as being wholly representative of the Ultra-Orthodox responses would be grossly unfair. In more recent years the work of four scholars in particular has begun to do a great deal to balance out this somewhat skewed view. Gershon Greenberg, ${ }^{6}$

\footnotetext{
2 Z. Braiterman, (God) After Auschwitz (New Jersey: Princeton University Press, 1998), 20.

${ }^{3}$ S. Katz, 'The Issue of Confirmation and Disconfirmation in Jewish Thought after the Shoah', in S. Katz, ed., The Impact of The Holocaust on Jewish Theology (New York: New York University Press, 2005), 52.

${ }^{4}$ Y. Teitelbaum, extract from section 110 of VaYoel Moshe (1961), found in translation at www.jewsagainstzionism. com.

${ }^{5}$ G. Greenberg, 'Ultra-Orthodox Jewish Thought about the Holocaust since World War II', in S. Katz, The Impact of The Holocaust on Fewish Theology, 134.

${ }^{6}$ See Greenberg's articles in S. Katz, The Impact of The Holocaust on Jewish Theology (New York: New York University Press, 2005), and part one of Katz et al, Wrestling With God.
} 
Nehemiah Polen, ${ }^{7}$ Eliezer Schweid $^{8}$ and Pesach Schindler $^{9}$ have all advanced the understanding of the charedi reaction to the Shoah. Importantly, their work (in combination with a number of the primary texts being published in English) has allowed a much deeper and thoughtful analysis of these responses to take place. What becomes evident from contact with the primary sources and through the work of these scholars is that Teitelbaum's extreme response is a symptom of the central Ultra-Orthodox concern of understanding everything as coming from God and as consequently being good in nature.

Pesach Schindler has described the problem as follows: "All that emanates from God is hesed (goodness, kindness), though it may be hidden (nistar) from man's finite perspective. Suffering must therefore be accepted with love (kabbalah be'ahavah) and mesirat nefesh (personal sacrifice) on the basis of faith (emunah) and unquestioning trust (bitahon) in God's ultimate justice."10 Teitelbaum's solution is one of the most simplistic and extreme ways to account for evil within such a theological context, and it is this extremity which has drawn attention to his response. It is not however the only possible solution, as will be seen below when we examine the response of Kalonymos Shapira. Before that examination is undertaken, we must first be familiar with the work of Zachary Braiterman, whose concept of antitheodicy will help shed some light on the surprising nature of Ultra-Orthodox responses to the Holocaust.

\section{A Constructive Critique of Braiterman's Concept of 'Anti-theodicy'}

The scholar Zachary Braiterman has argued that there is a deep strain of what he calls antitheodic thought in Holocaust theology. By this he means that as a discourse Holocaust theology has generally refused to justify God. He defines antitheodicy as, "the religious refusal to "justify," "explain," or "accept" the [3]relationship between God and evil". ${ }^{11} \mathrm{He}$ finds this refusal, albeit to different extents, in the work of Eliezer Berkovits, Richard Rubenstein and Emil Fackenheim, three of the most prominent post-Holocaust theologians to write in this area. From his examination of these thinkers he concludes that Holocaust theology has been largely antitheodic in nature. To fully understand this category of antitheodicy we must first understand the category of theodicy itself.

Theodicy is the attempt to account for evil and suffering by justifying their relationship to God. Judaism has traditionally held that God is a divinity of goodness, power and knowledge, a combination of attributes which, at face value at least, clash with the presence of evil and suffering in the world. This clash has over time come to be known as the problem of evil. This is a problem that has differing forms depending on which tradition is approaching the issue. For example, from the perspective of the Western philosophical tradition the problem of evil is essentially a logical trilemma stemming from the perceived infinite nature of God's attributes. Here, God becomes omnipotent, omniscient and all loving, and solving the problem becomes an exercise in pure logic.

${ }^{7}$ N. Polen, The Holy Fire: The Teachings Of Rabbi Kalonymus Kalman Shapira, The Rebbe of the Warsaw Ghetto (New Jersey: Jason Aronson, 1994).

${ }^{8}$ E. Schweid, Wrestling Until Day-break (Lanham: University Press Of America, 1994).

${ }^{9}$ P. Schindler, Hasidic Responses to the Holocaust in the Light of Hasidic Thought (New Jersey: KTAV Publishing House Inc, 1990).

${ }^{10}$ Schindler, Hasidic Responses to the Holocaust in the light of Hasidic Thought, $\mathrm{ix}-\mathrm{x}$.

11 Braiterman, (God) After Auschwitz, 20. 
For Jewish theology (unlike pure philosophy), this problem has to be worked out in a theological manner based upon the written and oral traditions of the faith, rather than in the strictly logical manner of the philosophical tradition. In Jewish tradition this theological problem of evil is intimately bound up with the concept of the Covenant, because it is this institution which binds the two parties, God and His people, together in an agreement which sets out what is expected of the two participants. God commands the laws by which the people should live and elaborates on what rewards can be expected if those laws are kept. However the consequences of not observing the law are also made clear; God can punish His people if they sin. We see here that the strictly logical problem of evil is not actually the primary concern for Jewish theology; rather it is a secondary problem when compared to the central issue of the Covenant, which defines the context and contours of the problem. The concept of the Covenant has generated one of the most prominent Jewish theodicies, which is that of retribution for sin. This is a response that explains, justifies and accepts suffering as a punishment from God due to human failure to keep God's laws, and as such it is a strongly theodic response to suffering. Chapter 32 of Deuteronomy, which stresses the perfect justice of God and the ubiquity of human sin in comparison, is one of the scriptural roots of such a theodicy.

It is this kind of strong theodicy that Rabbi Teitelbaum utilizes in his response to the Holocaust. He sees Zionism in particular as a sin against God's law and as a result of this sin the people were punished through the Holocaust. Of course this is not the only kind of theodicy generated by Judaism. There have been a number of differing theodicies developed through Jewish history, such as the rabbinic view of suffering which, particularly in the thought of Rabbi Akiba, emphasised an attitude of submission to God in the light of suffering. ${ }^{12}$ Rather than either seeing it as an occasion of strict punishment for sin, or questioning God's justice, Akiba sought to cultivate an attitude of submission which saw suffering as a precious experience. ${ }^{13}$ Another prominent theodicy has been the appeal to heaven as a final justification of the injustice and suffering of this world. In this response worldly injustice is understood as temporary injustice which will be rectified in the world to come, in which the innocent who have suffered will be redeemed.

What these theodicies have in common is that they all seek to justify and explain the suffering in one way or another, and from this we can see what it is that Zachary Braiterman is arguing when he says Holocaust theology has been significantly antitheodic in nature. He is suggesting that it has abandoned central Jewish theodicies like punishment for sin, in favour of responses which refuse to understand or accept evil and suffering as theologically justified. Instead they may deny the possibility of theodicy after catastrophic suffering like the Holocaust, or seek to protest the relationship between God and the [4]suffering. Of Holocaust theology Braiterman concludes, "They (the Holocaust theologians) deactivated central tropes like retribution, the world-to-come, afflictions of love, and prophetic rebuke by moving them out into the margins of their thought. In the process, post-Holocaust religious thought came to constitute a unique, antitheodic loop in the semiotic web of Jewish tradition." "14 Braiterman has built upon the work of Anson Laytner who, in his book Arguing

\footnotetext{
12 A. Laytner, Arguing With God: A Jewish Tradition (New Jersey: Jason Aronson, 1990), 115.

${ }^{13}$ Laytner, Arguing With God: A Jewish Tradition, 108.

${ }^{14}$ Laytner, Arguing With God: A Fewish Tradition, 167.
} 
With God: a Jewish Tradition (1990), ${ }^{15}$ identified and stressed a long history of Jewish protest/ argument with God in relation to human suffering. In this sense antitheodicy has long been a part of Jewish tradition, albeit in a peripheral manner when compared to the dominant theodic stream. Braiterman's analysis has much to commend it and his work has significantly advanced the understanding of what has occurred in Holocaust theology, but his argument does suffer from two problems, one being methodological, and the other being conceptual. Firstly, Braiterman's study is too narrow to justify the conclusion that Holocaust theology is broadly antitheodic in nature. Secondly, the term antitheodicy is too broad a term to apply to the variety of responses which abandon the dominant Jewish theodicies.

Braiterman reached his conclusions concerning Holocaust theology primarily through the examination of the works of Berkovits, Rubenstein and Fackenheim and although these are all key contributors to the post-Holocaust theological debate, they are not the only ones to have helped construct the discourse. Important and original contributions have been made by Ignaz Maybaum, David Blumenthal, Arthur Cohen, Irving Greenberg, Hans Jonas, Melissa Raphael, not to mention the many charedi responses. Therefore Braiterman's thesis concerning the antitheodic nature of Holocaust theology needs to be applied to a wider range of responses in order to judge whether Holocaust theology has been truly antitheodic in character, and if so to what extent. But even if the general application of antitheodicy to Holocaust theology is currently problematic, Braiterman's concept has nonetheless been useful since it has helped identify a significant characteristic of at least some of the key contributions to the field of Holocaust theology.

We have seen that Braiterman applies the term antitheodicy to responses which refuse to 'justify, explain, or accept' the relationship between God and evil. The problematic nature of this application can be seen by contrasting two hypothetical responses, both of which are significantly different yet could both be labelled as antitheodic, given Braiterman's definition of that term. The first hypothetical response is one that seeks no justification or explanation of the suffering, but instead focuses on divine mystery, arguing that the nature of God's relationship to the Holocaust is beyond humankind's limited comprehension. The second hypothetical response is one that seeks to protest against the suffering; bringing the event to God's attention by following the long Jewish tradition of arguing with God over His ways with creation, as in scripture when Abraham argues with God over the fate of Sodom and Gomorrah in Genesis 18.

These two responses are markedly different in their approach and nature, with the first rejecting immediate justifications or explanations, and the second refusing to accept the suffering as just but instead recommending religious protest as a proper response to the situation. The first is a theological response centred on divine mystery; the second is a theological response of protest, yet both could constitute antitheodicy in Braiterman's scheme, since they reject or ignore the traditional theodic answers which seek to explain and justify suffering. The concept of antitheodicy therefore becomes problematic because it covers responses that are markedly different in nature. This can be remedied by giving the term antitheodicy a more acute definition which is narrower in terms of the kind of responses to which it can be applied. To this writer's mind, antitheodicy as a term suggests a clear and active denial or impassioned rejection of the general project of theodicy. Consequently this

${ }^{15}$ Laytner, Arguing With God: A Fewish Tradition. 
term could be applied strictly to the types of response which focus on religious protest, or which deny that theodicy is possible in the first place. These kinds of responses easily fit within a category which suggests ideas of denial and rejection.

[5]Having given antitheodicy a stricter definition, we are left with the other kinds of responses that are neither strongly theodic nor antitheodic. These unclassified responses are now in need of categorization. The first hypothetical response examined above was one which focussed on divine mystery. Such a response does not really involve the idea of being passionately against the idea of theodicy, nor does it involve explaining or justifying the suffering in a positive sense. Rather it appears as acquiescence in the face of the limits of human cognition and comprehension. This kind of response may best be termed 'atheodicy'. This is a word which suggests a failure, relinquishing or relaxing of the traditional theodic attempt to explain and justify suffering, yet does not strongly indicate a turn toward the outright rejection of the possibility of theodicy, as is the case in antitheodicy. Neither does this word suggest the idea of religious protest.

The appeal to mystery and the limit of human comprehension are not the only kinds of response that could fall under this category of atheodicy. Any kind of response which seeks to respond to suffering with a type of religious meaning that does not seek to explain or justify the suffering could be counted as a form of atheodicy. For example, responses which seek to focus on the idea of God suffering with His people and providing consolation at the expense of explanation or justification could be deemed as atheodic. Similarly, appeals to healing and restoration from suffering and evil can be seen as atheodic, particularly if these responses focus on this activity in the absence of attempts at explaining or justifying the evil and suffering. The emergence of the term atheodicy generates a concept which, when applied to Holocaust theology, could help provide a more nuanced account of its character, since it lets us see with greater acuity the variety of religious responses that have been offered in response to the Shoah.

What emerges from this discussion of antitheodicy is a three-fold model of theological responses to evil and suffering: theodic, atheodic and antitheodic responses. In this model, the theodic responses would consist of efforts to offer full justifications and explanations of suffering, e.g. punishment for sin. The atheodic responses would consist of attempts to focus on divine mystery/theological silence, the idea of healing from suffering, and the idea of God suffering with His people. Antitheodic responses would consist of reactions which advocated protest to God over the suffering, or responses which deny the possibility of any theological meaning being found in suffering at all. With this in mind we may now turn to the Ultra-Orthodox response of Kalonymous Shapira: our new category of atheodicy coupled with the sharper definition of antitheodicy will now make it possible to show the complexity and depth of at least some of the Ultra-Orthodox thinking that has been generated in response to the Holocaust.

\section{Shapira's Response}

Rabbi Kalonymos Kalmish Shapira (1889-1943) was the leader of the Piacezna Chasidic community in Poland and came to be imprisoned in the Warsaw Ghetto during the early years of the Shoah. He suffered greatly during this time, not only through seeing many of 
his community perish, but also through losing a number of his closest family members including his mother, his son and his daughter-in-law. He was himself eventually murdered by the Nazis in the autumn of 1943. Yet in the years before his death he managed to write regular religious responses to what was happening in the form of commentaries on the Sidra (Portion of the Week). From 1939 to the summer of 1942 he produced the main body of his text, which was eventually published posthumously under the title Esh Kodesh (Sacred Fire, English translation 2004) after being found in a buried metal container during the post-war reconstruction of Warsaw. ${ }^{16}$ Esh Kodesh charts his response over the first three years of the war, and also contains additions made in late 1942 after the Warsaw Ghetto deportations. As with many Chasidic thinkers, Shapira's initial response was resolutely theodic in character. He sought to square the Holocaustal experience with the strongly held Chasidic conviction that God was the motivating force behind history and therefore the unfolding events must have a divine purpose.

[6] In much the same way as Teitelbaum would do after the War, Shapira initially constructed a response that viewed the suffering as punishments for Jewish sins, primarily the sin of assimilation. Shapira scholar Nehemia Polen comments on Shapira's initial stance: "The first year's derashah is very much in the traditional mode, with a heavy emphasis on religious failings and chastisement." ${ }^{17}$ This can be seen in September 1939 when Shapira wrote, "they strayed from the path, and in heaven there began the accusations against them. The charges stated that because of the great capriciousness of the Jewish people, because they were so steeped in their ignorance, they did not even acknowledge God's sovereignty ... Consequently, they were banished from the palace of the King, to dwell among people who torture them and cause them suffering." ${ }^{18}$ God, here as the king, is chastising the Jews for their sins. If Shapira's response had been limited to this early formulation, his reaction would have to be judged as essentially the same as Teitelbaum's response, i.e. strongly theodic, providing a full explanation and justification of the Shoah. But Shapira did not maintain this strongly theodic stance throughout the rest of his writings, and his attempt to explain and justify the sufferings became noticeably uncertain and hesitant as time progressed.

As the Nazi oppression grew in its severity, Shapira's response began to evolve theologically from its initially simplistic formulation of punishment for sin. This evolution in thought makes his response considerably more complex in nature, since these changes occurred whilst he was still trying to understand how the events carried divine meaning, something which caused great strain on his thinking and forced him into dexterous theological innovation. In Esh Kodesh Shapira was largely involved in what was essentially a theodic endeavour in that he desperately wanted to explain and justify theologically what was happening. Despite this strong theodic desire he began to generate various forms of atheodic and even antitheodic arguments in the ongoing process of responding to the Holocaust. The appearance of both atheodic and antitheodic elements ultimately makes clear the failure of the strong theodic project when confronted with the extreme evil that was manifesting around Shapira and his community.

\footnotetext{
${ }^{16}$ K. Shapira, Sacred Fire, trans. J. Worch (Lanham: Aronson, 2004).

17 Polen, The Holy Fire.

18 Shapira, Sacred Fire, 8.
} 
Before examining the antitheodic and atheodic content of Shapira's response a brief examination of his particular theodic arguments is necessary. Although we will see that his response came to incorporate atheodic and antitheodic ideas, it would be wrong to conclude that Shapira abandoned any attempt to explain what was happening in a theological sense. The central theodic idea that appears persistently throughout his response concerns the complex interrelationship between the mystical concepts of hesed (mercy) and gevurah/din (power/judgement). These are two (amongst ten) attributes of the divine that function within the mystical Godhead in the mystical tradition of the Kabbalah; a tradition of great influence on Chasidism. Time and again Shapira tries to work out the earthly suffering as a consequence of din obscuring hesed. Nehemia Polen expands on this aspect of Shapira's thought: "Rabbi Shapira no longer speaks of the enemy as the instrument of divine punishment. Rather, the enemy's words and actions are clearly labelled as evil. Nevertheless, even at this point, he maintains the Chasidic view that evil is always a perversion of the good, whose energetic spark it has captured and misdirects; but precisely because the vivifying power of evil is a distorted form of the good, it can be transmuted and "sweetened" back to its divine source." ${ }^{19}$ Showing how this tension links back to the idea that all that comes from God is good, Pesach Schindler further elaborates: "The apparent evil is merely a lower form of good, or the outer shell for the good, which is transformed into absolute good through man's acts of goodness." ${ }^{20}$ To the extent that Shapira had a theodicy (after his rejection of the idea of punishment for sin), it developed along these lines. He tried to understand all that was happening as being in someway a [7]hidden good, but this effort became increasingly hard for him to maintain and the effort became supplemented and even occasionally eclipsed by the presence of antitheodic and atheodic appeals.

The antitheodic content of Shapira's response will now be examined. This category of response has a limited but significant presence in his thought ${ }^{21}$ — something which is quite surprising given the Chasidic commitment to seeing all things as ultimately being from God and therefore good. Interestingly, this presence also goes against Braiterman's view of the Ultra-Orthodox responses as being theodically one-dimensional, and ironically provides evidence to strengthen Braiterman's assertion that Holocaust theology is a discourse composed of antitheodic stances and ideas.

Initially Shapira was against the idea of protesting or questioning God's justice, as is seen from his entry on 20 July 1940: “. . . they raise questions in their minds: How long will this go on? Who knows whether we will be able to bear it? Etc. As a result of the doubts, fears grow, the body is weakened, and the knees buckle. This is why it is most important to strengthen our faith to reject the questions and the thoughts, and to believe in God". ${ }^{22}$ Here we see a rejection of antitheodicy in its form of protest, and instead the developing of a position centred on unquestioning faith. The subsequent presence of antitheodicy shows the

\footnotetext{
${ }_{19}$ Polen, The Holy Fire.

${ }^{20}$ Schindler, Hasidic Responses to the Holocaust in the light of Hasidic Thought, 30.

${ }^{21}$ Nehemia Polen was the first to recognize properly the theme of religious protest in Shapira's thinking, though he did not put it in terms of antitheodicy, since Braiterman had not yet coined the term. Polen's recognition of protest in Shapira may be found in Polen, The Holy Fire.

${ }^{22}$ Shapira, Sacred Fire, 116.
} 
extent to which Shapira was struggling to understand the events within the confines of the idea that all which comes from God is good.

The first real evidence of antitheodicy in Shapira's thought appears in his entry on 28 September 1940: "But what can we do when they do not permit us to cry out, or even congregate for prayer, and we are forced to pray in hidden places, and every Jewish heart must lament this alone? At least in the depths of his heart, every Jew must shout out to God about it." 23 This need to 'shout out' intensifies in Shapira's thought only a week later when on October 31940 he wrote: "The screams that come of our tremendous bitterness and pain is indisputably our own voice. How could You bear to hear our pain and not have mercy, God forbid?" ${ }^{24}$ This is a very clear example of antitheodicy in its protest form, issued from within a perspective of faith. These two examples show that antitheodicy begins to creep into Shapira's response roughly a full year after the War began. This motif of religious protest appears numerous times from this point on in Esh Kodesh.

Shapira develops rules of acceptability in relation to this phenomenon of religious protest. In his entry for March 29 1941, he argued that religious protest was a valid option and not a sinful activity. Whilst writing about Exodus 5:21-23 where Moses asks God why He mistreated His people, Shapira stated: "If Moses had sinned with his question, how did he earn the privilege of this revelation of the name of God, $Y H V H ?{ }^{\prime 25}$ Later in that year (1941) on 15-22 December, in his writings for Chanukah, Shapira set out how protest was acceptable if done from within the context of prayer and faith. He exclaimed:

They question God, asking, "Why have You forsaken us? If we are being tortured in order to bring us closer to Torah and worship," they argue, "then why, on the contrary, is the Torah and everything holy being destroyed?" Now if a Jew utters these words in a form of prayer or supplication, as an outpouring out [8] of his heart before God, it is a good thing. But if, God forbid, he really is questioning - even if not God directly but his internal faith, God forbid - then may God protect us! ${ }^{26}$

Antitheodicy can, according to Shapira, have a sanctioned place even within Chasidic theology, which generally attempts to see all things as being for the good and directed by God.

In the form of religious protest antitheodicy does have a positive value for Shapira, as long as it is done from a perspective of faith and prayer, which consequently gives the protest legitimacy and acceptability. If done outside of these bounds the protest appears to become a kind of blasphemy which is damaging to the person engaged in it. Antitheodicy begins to feature particularly strongly toward the end of Esh Kodesh. On 27 June 1942, in one of his last entries, Shapira writes with great emotion:

... it is a marvel how the world exists after so much screaming. When the Ten Rabbis martyred by the Romans were suffering, the ministering angels cried out, "Is this Torah, and its reward?" A voice from heaven responded, "If I hear one more cry I will turn the whole world back to water." Yet now, immaculate children, purest angels, together with the greatest, holy Jews, are murdered

\footnotetext{
${ }^{23}$ Shapira, Sacred Fire, 124.

${ }^{24}$ Shapira, Sacred Fire, 131.

${ }^{25}$ Shapira, Sacred Fire, 164 note: It is unclear whether Shapira uses the Tetragrammaton in the original Hebrew text since the original is currently unavailable to this author. Given the context of the quotation it is possible that he did, but it is also possible that as a Chasidic rabbi he would have chosen not to do so due to its sacred nature.

${ }^{26}$ Shapira, Sacred Fire, 250-51.
} 
and butchered just because they are Jews . . . and the world does not turn back into water? It remains standing, steadfast, as though God is untouched by events, God forbid? ${ }^{27}$

All of this questioning and protest is still done from within a position of deep faith, but whereas at the start of the War antitheodic protest was rejected outright as a damaging practice, it has by the end of Esh Kodesh become assimilated into his response as a key component of his faith which, if done under the right circumstances, is both legitimate and positive in nature. Consequently his attempt to fully explain and justify the suffering endured by his community is cast in a very uncertain light as he wrestled with how the events can be good and directed by God when they were so horrific in nature.

Antitheodicy is not the only development which can be identified in Shapira's writings. The category of atheodicy is also to be found in his thinking. As we will now see, although Shapira never abandons his faith, his position eventually evolves into a position which no longer seeks to explain or justify the suffering, thus becoming essentially an atheodic response in its final phases. Shapira's response in Esh Kodesh actually exhibits differing forms of atheodicy; in particular appeals to divine mystery/silence, the idea of the suffering God, and the idea of healing from the suffering are all found to varying extents. We will however examine his response principally for the atheodic appeal to divine mystery and silence. This is because the appeal to theological mystery is of primary importance for making a response 'atheodic' in nature. For instance, a response could conceivably feature a call for healing and restoration yet still at the same time explain/justify the suffering theodically, e.g. the argument could be laid out: 'for our sins we have been punished, and now we must both repent and heal.' Appeals to the idea(s) of healing and/or divine suffering are not therefore necessarily atheodic in nature. They are context-sensitive and only become atheodic when used in conjunction with an appeal to mystery, or when the response focuses on healing/divine suffering exclusively, making no attempt to account for the suffering. The use of divine mystery by Shapira is therefore crucial to casting other aspects of his response in an atheodic light. The importance of this appeal consequently demands primary attention when examining Esh Kodesh for atheodic content.

Shapira's appeal to mystery and silence first appears as early as 2 December 1939, when he stressed silence in relation to the growing suffering whilst elaborating on Joseph's dream of the sheaves (Genesis 37:7). ${ }^{28}$ As the months progressed his appeal to silence increased and a year later on 21 December 1940 he wrote of God's knowledge being greater than that of human knowledge. He wrote of a suffering, "whose purpose is incomprehensible to us - to the contrary, it may appear purposeless". ${ }^{29}$ In his entry of [9]26 July 1941, whilst appealing to the idea that the times may indicate the birth pangs of the messiah, Shapira hints that even if the birth pangs explain the ongoing suffering as being necessary, they can do so only, "to the limits of our comprehension", ${ }^{30}$ which signifies that the process is more mysterious than humans can actually know or understand, thus leaving the suffering under-explained and significantly mysterious in nature.

During the Chanukah of 15-22 December 1941, Shapira stresses the limits of human knowledge of divine matters, by contrasting it with our knowledge of mundane things. He

Shapira, Sacred Fire, 328.

Shapira, Sacred Fire, 22.

29 Shapira, Sacred Fire, 160.

30 Shapira, Sacred Fire, 198. 
writes: "How can we expect or hope to understand these, God's actions, and then allow our faith to be damaged, God forbid, upon finding that we cannot understand them? If one blade of grass created by God is beyond our understanding, how much more unfathomable is the soul . . . and how much less even than this can we understand the mind of God? How could we possibly expect to grasp with our mind what God knows and understands?" 31 We find Shapira reinforcing faith in God by stressing the limited human intellect - a clear example of atheodicy since it does not explain or justify the suffering but rather focuses on the mystery of the divine and the narrow limits of human comprehension. Here, faith without explanation is the focus of Shapira. He picks this idea up again in his entry of 7 March 1942 where, whilst considering the Law of the Red Heifer (a purification law) of Numbers 19:1-2, he discusses whether we may ask about the meaning of a commandment and stresses that this Law of the Red Heifer "is Torah at the level of 'We will do and we will listen'. We do not conceptualize or even ponder the meaning of this Torah." 32 This he uses to urge his Chasidim to have a strong and un-questioning faith that all which is happening is for the good. He states: "We learn from this that the underlying meaning of the Law of the Red Heifer is a return to the level of "We will do and we will listen" - not to question, God forbid; just to believe that since everything is from God, it is good. Faith such as this both purges and atones, and advocates on behalf of the Jewish people." ${ }^{33}$ This is to say that sometimes there is no apparent explanation and in such cases the proper response is simply to have faith that all is happening for the good. This is an argument for faith which neither explains the suffering nor justifies it with reason. In fact it is the opposite; it is faith without understanding.

The fact that Shapira was stressing such a position during this time (early 1942) shows the level of dissonance within his thought, since it was, as we saw above, only the previous Chanukah that Shapira elaborated on the legitimacy of protesting to God over what was happening, yet here he appears to be saying that the events cannot be questioned or protested; rather they should be accepted. This highlights the tension in his thought as he tries to maintain an unquestioning faith in God over what was happening to him and his community. The atheodic content of his thought is seen in his faith that all must be good even though he cannot explain how or why it is for the good, and, in combination with this, the antitheodic elements appear to act as a means to vent his anguish at the ever unfolding and incomprehensible suffering. In this sense the two may not be as contradictory as they first seem, but nonetheless these two poles of faith and protest are hallmarks of a deeply troubled and anguished response.

In one of the very last footnote additions to his manuscript, Shapira describes the circumstances facing the remnants of the Warsaw Ghetto in late 1942. He wrote: "Those individuals who survive, pitiful and few, are broken in slavery and Egyptian bondage, downtrodden and terrified for their lives. There exist no words with which to lament our woes." ${ }^{34}$ Here, in one of his final additions, all attempts at a theodicy which explains and justifies the suffering appear to have ended. There is no talk of punishment for sin and no words of explanation or justification. Shapira is left with only a faith that redemption will

\footnotetext{
31 Shapira, Sacred Fire, 251.

32 Shapira, Sacred Fire, 307.

33 Shapira, Sacred Fire, 308

34 Shapira, Sacred Fire, 209.
} 
come, "in [10]the blink of an eye". ${ }^{35}$ Remembering his initial theodic reaction to the Holocaust, Shapira's response can now be seen clearly to shift from a position of 'punishment for sin' which explains and justifies the events, to a position of extreme faith which incorporated a legitimized form of religious protest and, in the final account, no longer sought to present an effective explanation or justification of the suffering. Shapira's faith remained throughout his whole writing, but his theodic response morphed over time into a theology in which atheodic and antitheodic elements played increasingly important and central roles.

\section{Conclusion}

What then can be concluded from this short examination? Shapira's response proves one thing conclusively: that Ultra-Orthodox thought is not as recidivistic as has often been thought. In fact through Shapira's response we see that Ultra-Orthodox thought did not always respond to the Holocaust by appealing to a relatively uncomplicated theology of punishment and sin. Although the idea of punishment for sin was appealed to by some Chasidic thinkers this was certainly not the case for all, especially in the case of Shapira, who abandoned such an explanation early on in the War. What this common stereotype of the Chasidic responses really masks is a much deeper theology in which worldly events have to be squared theologically with the idea that all things are from God and therefore ultimately for the good. This challenge can manifest answers along the lines of punishment for sin, but this is far from the only possibility. Shapira's atheodic and antitheodic appeals, both of which grow throughout Esh Kodesh, show that Shapira was able to develop other possibilities (namely divine mystery and religious protest) within a Chasidic theological framework.

We have seen how divine mystery and religious protest become prominent features of his thought, and these two are only some of the theological possibilities he develops. A comprehensive and detailed analysis of his work would show that he developed other important theological concepts which helped form his response, such as the idea of God's suffering and a focus on healing from the catastrophe. As indicated above, the theodical side to his theology focussed on the idea of working out suffering in mystical terms of judgement and mercy within the Kabbalistic understanding of the Godhead. All of these are of importance and interest, and a testament to the complexity of Shapira's theological response. What we can conclude here however is that his theology shows that faith did not have to be buttressed by comprehensive theological explanations or justifications when it came to encounters with extreme evil and suffering.

Shapira's response may provide evidence to confirm a conclusion made by Gershon Greenberg, who has observed that one of the main characteristics of Ultra-Orthodox responses given from within the Shoah is that of an appeal to silence: "Concepts of the path from the disastrous present to the salvational future differed according to the respective thinkers' time-space position. When the experience of tragedy was direct and the catastrophe was simultaneously subjective and objective, the attempt to verbally express the path was

35 Shapira, Sacred Fire, 209. 
abandoned." ${ }^{36}$ Shapira's response, which was given from within the Holocaust temporally and spatially, clearly shows this abandonment of verbally expressing the way to a salvational future from the darkness of the Holocaust, primarily in his atheodic appeal to divine mystery which comes to largely replace the attempt to explain what is happening theologically and how it relates to redemption.

Through these antitheodic and atheodic appeals Shapira was able to respond both meaningfully and sensitively to the mass suffering of his community in a way that often offered hope despite the communal agony. Particularly in his antitheodic innovations, he developed a cathartic tool for expressing feelings of anger, uncertainty and fear over what was happening. For Shapira, the concepts of atheodicy and [11]antitheodicy offer ways to both understand and cope with suffering in ways that do not require full explanation or justification of the events. Where the strongly theodic answers such as punishment for sin seemingly fail for those who are living through episodes of catastrophic suffering, these two theological options of atheodicy and antitheodicy provide ways of facing the problem through a recognition of the divine mystery of things, and through a theological mechanism of religious protest.

This is the first time (to my knowledge) that the fully defined categories of antitheodicy and atheodicy have been applied to, and recognized within, Shapira's response. Others may have noticed Shapira's use of religious protest (particularly Nehemia Polen ${ }^{37}$ ), but not as an example of the category of antitheodicy as defined by Braiterman or as refined in this article. Similarly the theme of divine mystery may have been recognized within Shapira's response (as with Gershon Greenberg's observation of silence as being an important feature of responses from within the Shoah) but not as an example of the category of atheodicy as here defined.

In more broad terms we may conclude that the category of atheodicy helps in further understanding the nature of Holocaust theology by providing a new analytical tool with which to analyse the responses within this field. In combination with theodicy and antitheodicy, the category of atheodicy helps comprehend the character of a given response by revealing the different strands which together form that particular theological response. As in the case of Shapira, the finer details of a theologian's thought can be revealed, allowing for a deeper appreciation of his or her thinking, which in turn can help us to see how a body of responses (in this case the Ultra-Orthodox) are more nuanced and complex than may initially have been thought. To be sure, this is not the only way such results can be gained, but it does provide a particularly clear taxonomy of responses from which to analyse a theological response. When a response is developed over a significant period of time it is also possible, using the three-fold model given here, to see how a thinker's theodic efforts may transform and evolve either within their own intellectual life, or in response to a specific event they lived through or confronted. This allows the theological impact of events (such as the Holocaust) upon Jewish thought to be seen with greater clarity and depth.

\footnotetext{
${ }^{36}$ G. Greenberg, Introduction to Part 1 'Ultra-Orthodox Responses During And Following The War' in Katz et al, Wrestling With God, 23.

${ }_{37}$ Polen, The Holy Fire.
} 


\section{BIBLIOGRAPHY}

Braiterman, Z., (God) After Auschwitz (New Jersey: Princeton University Press, 1998).

Katz, S., ed., The Impact of The Holocaust on Jewirsh Theology (New York: New York University Press, 2005).

Katz, S., S. Bider and G. Greenberg, eds., Wrestling With God: Jewish Responses During and After The Holocaust (New York: Oxford University Press, 2006).

Laytner, A., Arguing With God: A Jeweish Tradition (New Jersey: Jason Aronson, 1990).

Polen, N., The Holy Fire: The Teachings Of Rabbi Kalonymus Kalman Shapira, The Rebbe of the Warsaw Ghetto (New Jersey: Jason Aronson, 1994).

Shapira, K., Sacred Fire, trans. J. Worch (Lanham: Aronson, 2004).

Schindler, P., Hasidic Responses to the Holocaust in the Light of Hasidic Thought (New Jersey: KTAV Publishing House Inc., 1990).

Schweid, E., Wrestling Until Day-break (Lanham: University Press Of America, 1994).

Teitelbaum, Y., extract from section 110 of VaYoel Moshe (1961), found in translation at www. jewsagainstzionism.com 